\title{
Industrial Potentiality of Alluvial Clays Deposits from Cameroon: Influence of Lateritic Clayey Admixture for Fired Bricks Production
}

\author{
Aubin Nzeugang Nzeukou ${ }^{1,2,3 *}$, Véronique Kabeyene Kamgang ${ }^{2}$, Robert Eko Medjo ${ }^{2}$, \\ Uphie Chinje Melo ${ }^{1}$, André Njoya ${ }^{1}$, Patrick Ninla Lemougna ${ }^{1}$, Nathalie Fagel $^{3}$ \\ ${ }^{1}$ Local Materials Promotion Authority (Mipromalo), Yaounde, Cameroun \\ ${ }^{2}$ Laboratory of Alterology and Engineering Geology, Yaounde, Cameroun \\ ${ }^{3}$ Laboratory of Clays, Geochemistry and Sedimentary Environments (AGEs), Boulevard du Rectorat, \\ 17 (Bât. B18) Sart Tilman, University of Liege, Liège, Belgium \\ Email: *nzeuk@yahoo.fr
}

Received May 2, 2013; revised June 18, 2013; accepted June 28, 2013

Copyright (C) 2013 Aubin Nzeugang Nzeukou et al. This is an open access article distributed under the Creative Commons Attribution License, which permits unrestricted use, distribution, and reproduction in any medium, provided the original work is properly cited.

\begin{abstract}
The cartography and characterization of an alluvial clay deposit from Ebebda (Central region of Cameroon) were carried out in order to assess its suitability for the production of fired clay bricks. The clayey area investigated is $\sim 50,000 \mathrm{~m}^{2}$ with an average thickness of the exploitable layer of $2.2 \mathrm{~m}$, suggesting a deposit of about $\sim 2.2 \times 10^{5}$ tonnes of clay. Mineralogy, physico-chemical and thermal analyses as well as firing properties were performed on representative clay samples. Kaolinite and quartz are the major minerals associated to illite. Upon heating to $900^{\circ} \mathrm{C}-1200^{\circ} \mathrm{C}$, the linear shrinkage varies from $1.5 \%$ to $15 \%$, the water absorption from $1.5 \%$ to $24 \%$ and the bending strength from 2 to $12 \mathrm{MPa}$. The admixture of lateritic clays (widely available) at $50 \%, 60 \%, 70 \%$ and $80 \%$ allow to decrease the shrinkage and bending strength, and to increase the water absorption. Overall, properties were satisfying the requirement for fired brick with $70 \%$ of laterite in the mixture.
\end{abstract}

Keywords: Alluvial Clay Deposit; Characterization; Lateritic Clay Admixture; Brick; Cameroon

\section{Introduction}

Clays are widely used as raw materials in the field of construction, fine ceramics, pharmaceutical industry, oils decoloration, etc. $[1,2]$. The evaluation of this natural resource has a ripple effect on the economic development of countries. The potentialities of clayey minerals are generally linked to their structure, composition and physical properties [3]. The exploration of new clay deposits in developing countries such as Cameroon could significantly contribute to socio-economic development [4]. Cameroon's basement contains industrial clays of various origins (sedimentary, residual and alluvial) $[5,6]$. Most of previous studies remained preliminar, providing no information on the physico-chemical properties of clays as well as their quantification. This study presents field data of Ebebda's clay deposit along the Sanaga River. The clay deposit was assessed and the physicochemical and mineralogical compositions were determined

${ }^{*}$ Corresponding author. in order to evaluate their suitability for the production of fired clay bricks. Laterite residual soils available in $\mathrm{Ca}-$ meroon on nearly $67 \%$ of the national territory have been widely studied. Their composition contains $\mathrm{Si}, \mathrm{Al}$ and $\mathrm{Fe}$ with kandites (kaolinite, halloysite) as the main clays minerals. Quartz, goethite and hematite are predominant minerals with rutile and anatase as accessory minerals. All these minerals derive from the weathering of the gneissic basement of the Yaounde's area [7]. The infrared spectra of kaolinite mineral in lateritic soil present a weak stretching band at $3668 \mathrm{~cm}^{-1}$ reflecting their low crystallinity [8]. The residual clayey layer (upper part of the profile) is common in the Yaounde area $[9,10]$ and according to their typology, morphology and distribution, it is generally observed in the western part of Yaounde on the hills with altitudes between 780 and $800 \mathrm{~m}$. The thickness varies from 3 to $6 \mathrm{~m}$ [8]. Despite a few report on the valorization of the lateritic clayey soils in low fired brick production $\left(975^{\circ} \mathrm{C}\right)$ with no admixture [11], many studies show that the fusibility of these residual 
clays and the durability of fired bricks derived cannot be complete due to the mineralogical content of these raw materials $[5,8]$. In order to better valorize lateritic clayey soil in brick manufacture, the mixture with alluvial clays could present better physical properties. Here, our aim is to test this approach on clayey deposit from central Cameroon. The admixture with lateritic clayey soil was also made in order to reduce the potential production costs. The ceramic properties of the pure fired clay as well as those admixed with lateritic clay were determined.

\section{Material and Method}

\subsection{Material and Geological Outline}

The studied alluvial clays are collected from the locality of Ebebda in the central region of Cameroon. The details on studied area are presented on Figure 1. The lateritic clayey soil used as admixture is collected from EtougEbe $\left(3^{\circ} 54^{\prime} \mathrm{N}, 11^{\circ} 31^{\prime} \mathrm{E}\right)$, a suburb of Yaoundé. The Cameroon's geology is mainly composed (about 90\%) of Precambrian formations dominated by the Ntem Complex and the Panafrican Chain [12,13]. The Sanaga Basin belongs to the Panafrican Chain (500 - $600 \mathrm{Ma}$ ) with the outcropping rocks are made of micaschists, gneisses, migmatites and granites known as "Yaoundé series". Studied clays probably derive from the weathering of basement rocks. These rocks are derived from a high-pressure metamorphism of volcano-sedimentary materials. The weathering products have been undergone erosion, transport and sedimentation along the Sanaga River.

\subsection{Method}

\subsubsection{Clay Deposit Estimation and Sampling}

Field campaigns were allowed to establish a geological diagnosis (nature, size, thickness, geometry, homogeneity, accessibility, etc.) of the alluvial clays in the studied area. The exploration and description of outcrops and the cartography of the deposits were done using classical methods of geological survey linked to quantitative evaluation of geomaterials as clays (pit digging, auger drilling, boring holes, etc.). The reserve was estimated on the basis of the drill depth and the studied area $[14,15]$. During fieldworks, about sixty drillings were performed using a hand auger down to a maximum depth of $5 \mathrm{~m}$. The different steps include: 1) implementation of the sample survey plan, 2) opening of transects providing access to sampling points, 3) realization of 60 pits of 3 to $5 \mathrm{~m}$ depth, 4) realization of two observational pits of $1 \mathrm{~m}^{2}$ and $2 \mathrm{~m}$ depth.

The geographical coordinates of polls and benchmarks were collected using a Garmin type GPS. These coordinates once converted were introduced into the MapInfo software to produce maps. The satellite imagery (Google
Earth) was used to georeferencing and to digitize the documents. The mesh used was $50 \mathrm{~m}$ in order to produce a map at 1/5000 (Figure 1). The color of the different profile layers was determined using the Munsell code [16]. The samples were selected according to clay facies variation. The "true" density of clay sample was obtained using an automatic pycnometer with helium (type Micromeritics brand AccuPyc, 1330 V2 0.3N Norcross USA).

\subsubsection{Clay Preparation and Characterization}

Average clay samples of selected profile (P2, E2, E6, E14, E18, E46, E50 and E59) and each of different layers of pit (P2a, P2b and P2c) have undergone mineralogical analysis by X-ray diffraction. The sample P2 representing the average of the clay facies (P2a, P2b and P2c) from the pit was also characterized by IR, DTA/DTG, chemical, physical and technological analyses.

X-ray diffraction was performed with a Brucker D8Advance diffractometer device (copper $\mathrm{K} \alpha 1$ radiance, $\lambda=$ $1.541838 \AA, \mathrm{V}=40 \mathrm{kV}, \mathrm{I}=30 \mathrm{~mA}$ ) at the University of Liege, Belgium.

The measurements were carried out in the $2 \theta$ range from $2^{\circ}$ to $45^{\circ}$ with step size of $0.02^{\circ}$ and time per step $2 \mathrm{~s}$. Bulk mineralogy and clay fraction were obtained according to [17]. Interpretation of mineral phases was carried out by using Eva software. Qualitative and semiquantitative estimation are estimated with corrective factors [18-21].

The infrared spectra (IR) were recorded on a Nicolet NEXUS spectrometer. Two milligrams of sample was mixed with $180 \mathrm{mg}$ of $\mathrm{KBr}$ to form a tablet used for analysis. Chemical analysis was performed by X-ray Fluorescence Spectroscopy (XRF) with S4 PIONNER Brucker equipment on fine $(<250 \mu \mathrm{m})$ powder pellet at Mipromalo, Cameroun. Simultaneous DTA-DTG experiments were performed using a multidetector high temperature calorimeter (Setaram 85), in dry air condition with a heating rate of $5^{\circ} \mathrm{C} / \mathrm{min}$ from room temperature to $1200^{\circ} \mathrm{C}$ at ENSCI, Limoges, France.

The grain size distribution was determined by wet sieving of the fraction $>80 \mu \mathrm{m}$ and gravity sedimentation for the fraction between 80 and $2 \mu \mathrm{m}$ and the Atterberg limits were obtained by the Casagrande method using ASTM norms, respectively D-422 and D-4318 [22, 23].

Five compositions of bricks were prepared by adding $0 \%, 50 \%, 60 \%, 70 \%$ and $80 \%$ of laterite (L) in the alluvial clay (P2). The alluvial clay and the laterite were first dried and sieved $(\varnothing<1 \mathrm{~mm})$ before mixing and hand homogenization. The water content is about $15 \%$, varied from $14 \%$ to $15 \%$. The test specimens $(80 \mathrm{~mm} \times 40 \mathrm{~mm}$ $\times 18 \mathrm{~mm}$ ) were made using a $10 \mathrm{KN}$ hydraulic press, then dried at room temperature for $72 \mathrm{~h}$, oven-dried $\left(105^{\circ} \mathrm{C}\right)$. The dried samples were fired at $900^{\circ} \mathrm{C}, 1000^{\circ} \mathrm{C}$, 

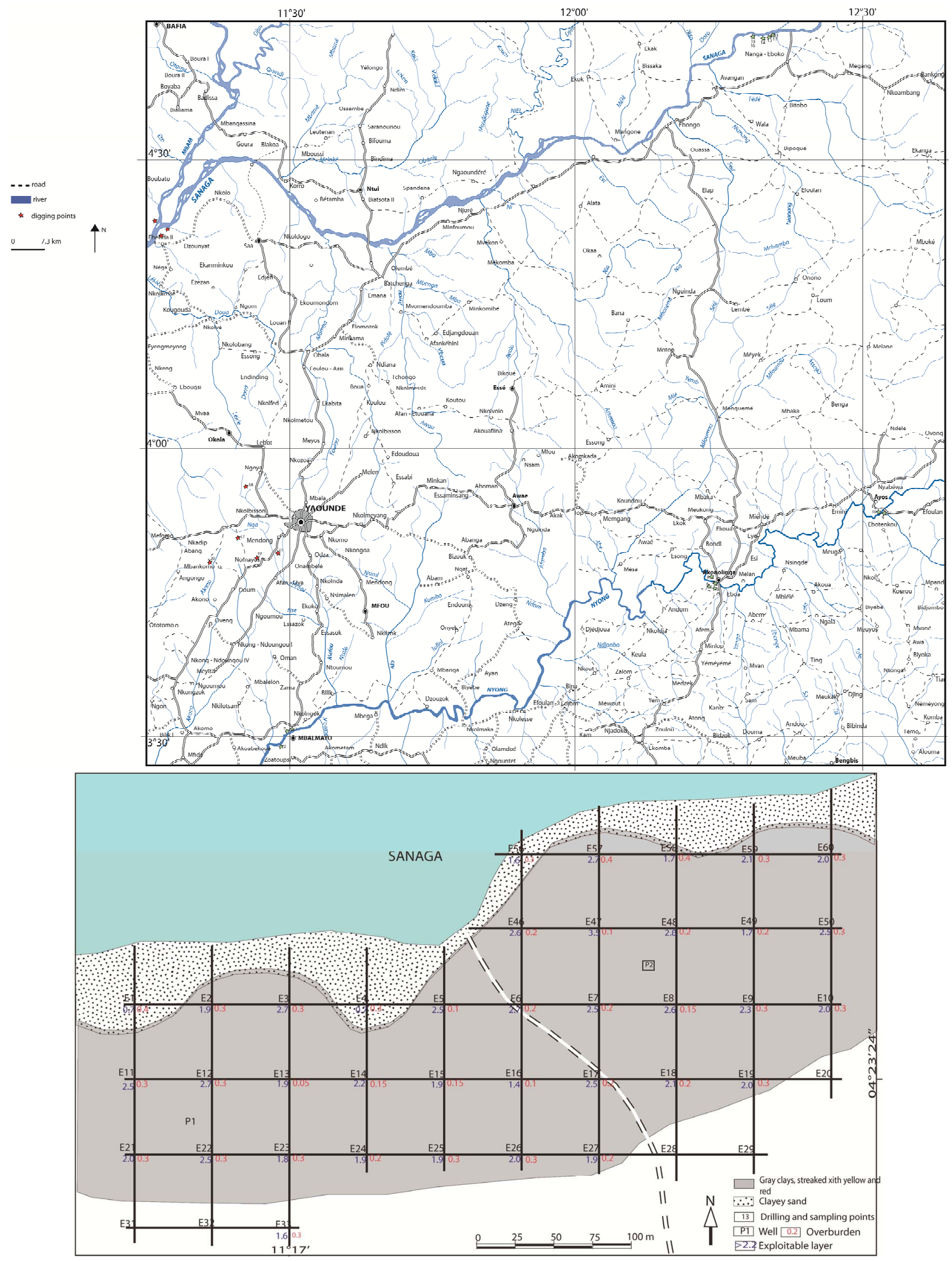

Figure 1. Location of Ebebda's area and sample survey plan for clay deposit along the Sanaga River. 
$1100^{\circ} \mathrm{C}$ and $1200^{\circ} \mathrm{C}$ for a period of 5 hours at a heating rate of $5^{\circ} \mathrm{C} / \mathrm{min}$ in a MultiMate furnace. The firing shrinkage $100\left(\mathrm{~L}_{\mathrm{m}}-\mathrm{L}_{\mathrm{f}}\right) / \mathrm{L}_{\mathrm{m}}$ were obtained according to the relative variation in the length of the specimen, where $L_{m}$ is the length of the mould and $\mathrm{L}_{\mathrm{f}}$ is the length of the fired specimen. The water absorption and bending strength were determined using ASTM norm C373-72 and C67477 respectively [24,25].

\section{Results and Discussion}

\subsection{Field Data and Reserves Estimation of the Alluvial Clay}

The elevation of Sanaga valley at Ebebda varied between $200 \mathrm{~m}$ and $500 \mathrm{~m}$. The vegetation mainly consists of swamp forest on the right bank while the left bank is mostly covered with savanna. The studies were carried out on both banks. However, the right bank is characterized by a stony soil poor in clay minerals, limiting prospection through depth. The left bank area shows some clay deposits and the profiles are made by five layers (Figure 2): organic soil $(0-40 \mathrm{~cm})$, fine gray clay mottled with yellow $(40-130 \mathrm{~cm})$, fine gray clay mottled with red $(130-180 \mathrm{~cm})$, fine gray clay mottled with light brown $(180-280 \mathrm{~cm})$ and clayey sand $(>280 \mathrm{~cm})$. For each profile, the thickness of the exploitable layer is from 2 to $2.5 \mathrm{~m}$. The estimated average thickness of clays is $2.2 \mathrm{~m}$ with an approximate area of 5 ha. This gives an average volume of clay per hectare of $22,000 \mathrm{~m}^{3}$. Considering the density of clay $\left(2520 \mathrm{~kg} / \mathrm{m}^{3}\right)$ determined by the Micromeritics AccuPyc device, the clay quantity is estimated at $110,000 \mathrm{~m}^{3}$ or approximately 220,000 tonnes. Such clay ore may be used by an industry with a production capacity of 20,000 tonnes/year can over a pe-

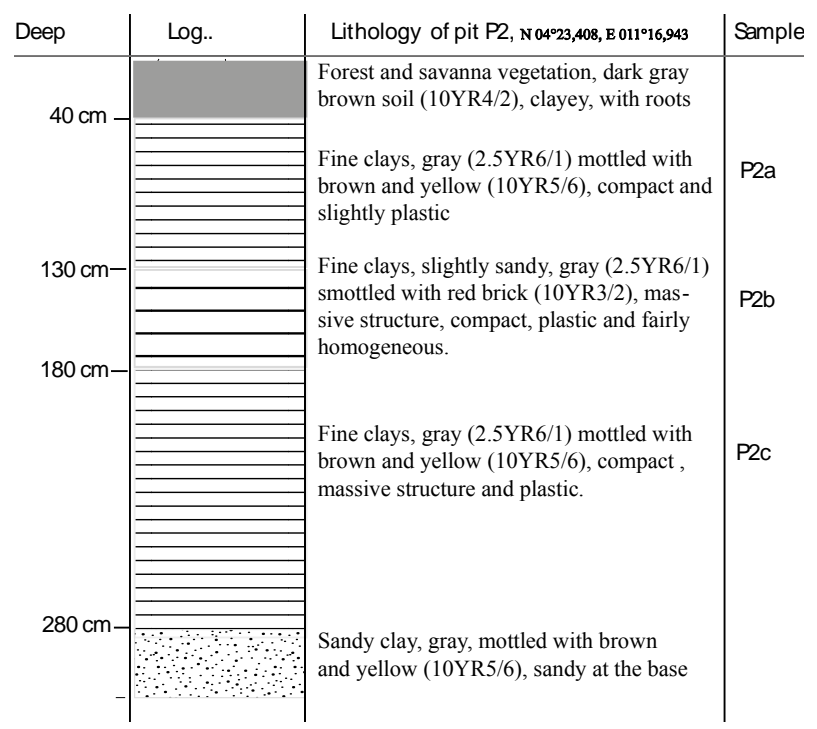

Figure 2. Profile of alluvial clay at the locality of Ebebda, Cameroon. riod of 14 years.

\subsection{Mineralogical and Physico-Chemical Characterization}

The air-dried XRD pattern of the clays studied (Figure 3) indicates the predominance of quartz $\left(2 \theta, 27.3^{\circ}\right)$ and kaolinite $\left(2 \theta, 12.06^{\circ}\right)$. The proportion of the different minerals varies from one sample to another: quartz varies from $43 \%(\mathrm{P} 2)$ to $62 \%$ (P2a), K-feldspar from $0 \%$ (E50) to $4 \%$ (E46), kaolinite from 33\% (E59) to 41\% (P2c), illite from $5 \%(\mathrm{E} 50)$ to $10 \%(\mathrm{P} 2 \mathrm{c})$, smectite from $0 \%(\mathrm{E} 2)$ to $3 \%(\mathrm{P} 2)$, goethite from $1 \%(\mathrm{E} 59)$ to $4 \%(\mathrm{E} 2)$ and hematite from $0 \%(\mathrm{E} 2)$ to $4 \%(\mathrm{E} 59)$. The average data of the main minerals are quartz (49\%), kaolinite (33\%), illite $(7 \%)$ and K-feldspar (2\%). Goethite and hematite are significantly present $(\sim 3 \%)$ while smectite and anatase are in trace $(<2 \%)$ (Table 1).

The IR spectra indicate the presence of two minerals: kaolinite and an oxyhydroxide-rich mineral (Figure 4). The characteristics peaks of kaolinite appear at 3695 $\mathrm{cm}^{-1}$ (v1), $3655 \mathrm{~cm}^{-1}$ (v3) and $3619 \mathrm{~cm}^{-1}$ (v4). A well crystallized kaolinite generally presents four $\mathrm{OH}$-stretching bands: v1 at $3695-3696 \mathrm{~cm}^{-1}$; v2 at $3675-3668$ $\mathrm{cm}^{-1}$; v3 at $3655-3652 \mathrm{~cm}^{-1}$ and v4 at $3619-3620 \mathrm{~cm}^{-1}$ [26]. The absence of a well defined peak of $v 2$ (3675 $3668 \mathrm{~cm}^{-1}$ ) suggests that the kaolinite presents in the alluvial clay (P2) is disordered or poorly crystallized along the $(\mathrm{a}, \mathrm{b})$ axes [27]. The disordered or poorly crystallized character of the kaolinite present in the alluvial clay is also evidenced by the absence of $\mathrm{Al}_{2} \mathrm{OH}$ bending bands at $938 \mathrm{~cm}^{-1}$, suggesting stacking faults along the "c" axis [28]. This confirms their sedimentary origin $[28,29]$. The band at $3434 \mathrm{~cm}^{-1}$ is attributed to the $\mathrm{OH}$ vibration of hydroxyl alumina [30]. The wide band of low absorption observed around $1626 \mathrm{~cm}^{-1}$ is attributed to the presence of water molecules or possibly others radicals such as amorphous constituents of aluminosilicates. The shoulder observed around $2300 \mathrm{~cm}^{-1}$ is due to a default of the analytical device.

The thermal curves (DTG/DTA) of the alluvial clay (Figure 5) have evidenced between $0^{\circ} \mathrm{C}-200^{\circ} \mathrm{C}$, a first weight loss (about 2\%) due to the departure of the hygroscopic water also materialized by the first small endotherm peak at $72^{\circ} \mathrm{C}$. The small endotherm peak observed at $249^{\circ} \mathrm{C}$ with $0.78 \%$ of weight loss could arise from the deshydroxylation of iron or alumina oxyhydroxides. Between $400^{\circ} \mathrm{C}$ and $600^{\circ} \mathrm{C}$, there is a continuous weight loss $(7.22 \%)$ due to the departure of the structural water of kaolinite (second endothermic at $493^{\circ} \mathrm{C}$ ). This particular weight loss is generally linked to the amount of kaolinite present in the clay [31]. On the other hand, the broad exothermic band between $100^{\circ} \mathrm{C}$ and $300^{\circ} \mathrm{C}$ is linked to the combustion of organic matter and the small endotherm peak at $572^{\circ} \mathrm{C}$ is due to the trans- 


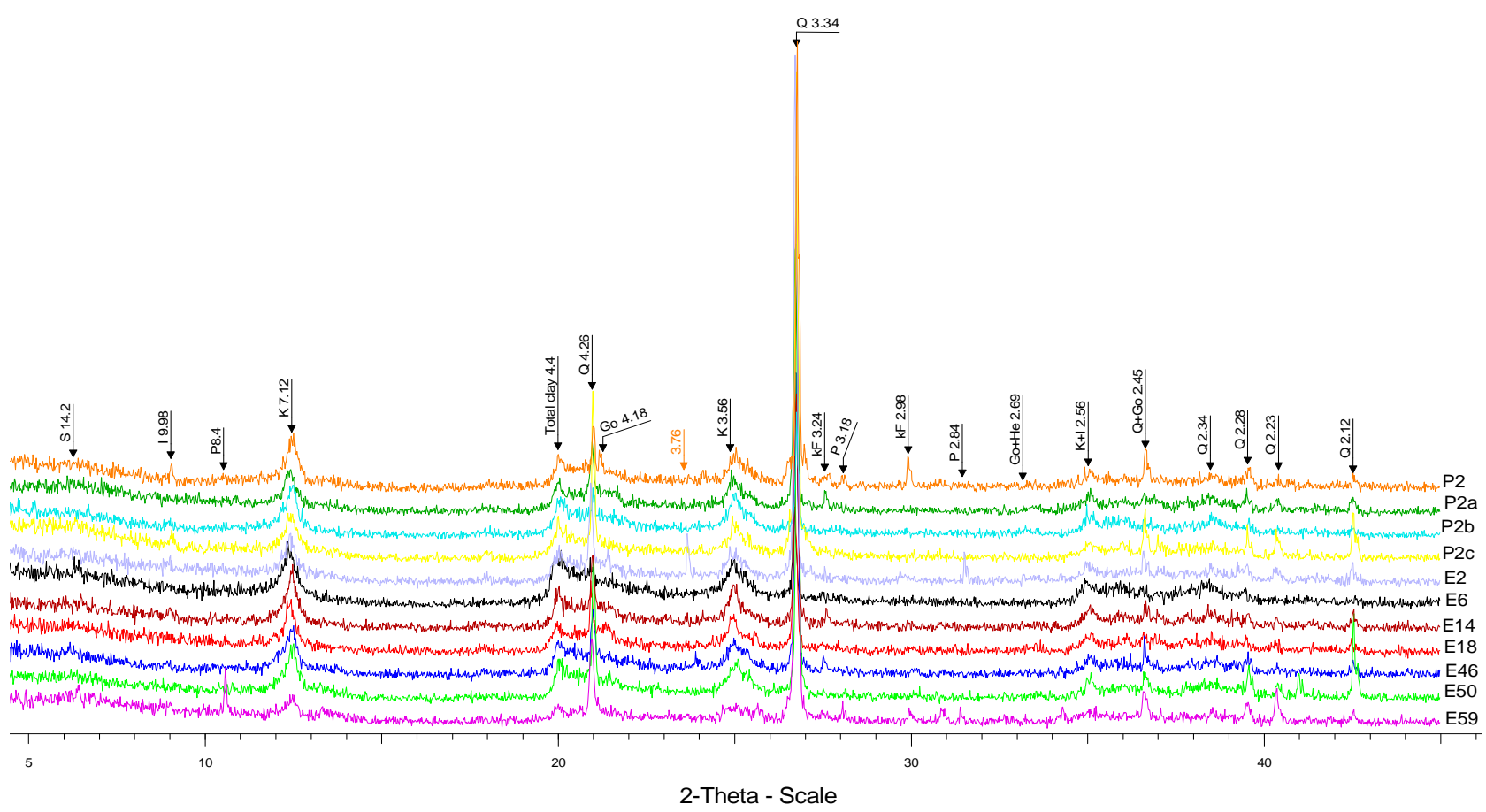

Figure 3. Bulk mineralogy of alluvial clays from the locality of Ebebda, Cameroon.

Table 1. Some properties of used clayey soils.

\begin{tabular}{ccccccccccc}
\hline Sample & Depth $(\mathrm{cm})$ & Total Clay & Quartz & K-Feldspath & Anatase & Goethite & Hématite & Kaolinite & Illite & Smectite \\
\hline P2 & $30-300$ & 46 & 43 & 3 & 2 & 2 & 2 & 36 & 9 & 3 \\
P2a & $30-100$ & 30 & 62 & 3 & 1 & 3 & 0 & 24 & 6 & 1 \\
P2b & $100-230$ & 41 & 48 & 3 & 2 & 2 & 4 & 34 & 6 & 1 \\
P2c & $230-300$ & 53 & 43 & 0 & 2 & 2 & 0 & 41 & 10 & 2 \\
E2 & $40-180$ & 43 & 49 & 3 & 2 & 4 & 0 & 35 & 7 & 0 \\
E6 & $150-290$ & 46 & 48 & 2 & 2 & 2 & 0 & 37 & 7 & 2 \\
E14 & $15-100$ & 43 & 49 & 2 & 1 & 3 & 3 & 33 & 8 & 1 \\
E18 & $90-220$ & 42 & 48 & 2 & 2 & 4 & 3 & 33 & 8 & 0 \\
E46 & $80-160$ & 44 & 47 & 4 & 1 & 2 & 2 & 35 & 7 & 2 \\
E50 & $100-170$ & 42 & 51 & 0 & 3 & 2 & 2 & 36 & 5 & 1 \\
E59 & $170-190$ & 34 & 51 & 4 & 3 & 1 & 4 & 24 & 9 & 2 \\
Average & & 42 & 49 & 2 & 2 & 2 & 2 & 33 & 7 & 1 \\
\hline
\end{tabular}

formation of quartz alpha to quartz beta [32]. The LOI result confirms the presence of organic matter which represents the volatile materials. No further weight loss is observed above $800^{\circ} \mathrm{C}$. The last small endothermic peak observed between $800^{\circ} \mathrm{C}$ and $1000^{\circ} \mathrm{C}$ is due to the production of silicate liquid deriving from the melting of feldspar, while the exothermic band corresponds to the formation of spinel or mullite phase [33].

The physico-chemical properties of the alluvial clay and the laterite used for the technological tests (Table 2) show $\mathrm{SiO}_{2}(60 \%), \mathrm{Al}_{2} \mathrm{O}_{3}(14 \%)$ and $\mathrm{Fe}_{2} \mathrm{O}_{3}(7 \%)$ as the predominant oxides of the alluvial clay. The lateritic soil used contains also the same oxides, but it is less siliceous $(40 \%)$ and is richer in alumina (32\%) and iron (12\%). The sum of bases $\left(\mathrm{K}_{2} \mathrm{O}, \mathrm{MgO}, \mathrm{CaO}\right)$ is low in the lateritic soil $(<1 \%)$, but slightly higher $(1.37 \%)$ in the alluvial clay.

The particle size distribution of the alluvial clay is 
Table 2. Properties of studied clays.

\begin{tabular}{|c|c|c|c|c|c|c|c|c|c|c|c|c|c|c|c|c|}
\hline \multirow[b]{2}{*}{ Sample } & \multicolumn{8}{|c|}{ Physical properties (\%) } & \multicolumn{7}{|c|}{ Chemical composition (wt. \%) } & \multirow[b]{2}{*}{ LOI } \\
\hline & $\begin{array}{l}\text { Density } \\
\mathrm{g} / \mathrm{cm}^{3}\end{array}$ & Clay & Silt & Sand & Fines & Wl & $\mathrm{Wp}$ & Ip & $\mathrm{SiO}_{2}$ & $\mathrm{Al}_{2} \mathrm{O}_{3}$ & $\mathrm{Fe}_{2} \mathrm{O}_{3}$ & $\mathrm{CaO}$ & $\mathrm{MgO}$ & $\mathrm{K}_{2} \mathrm{O}$ & $\mathrm{TiO}_{2}$ & \\
\hline Alluvial clay (P2) & 2.52 & 72.9 & 19.6 & 7.34 & 89.7 & 82.1 & 35.8 & 46.3 & 61.5 & 14.7 & 7.6 & 0.05 & 0.28 & 1.19 & 1.38 & 11.89 \\
\hline Lateritic soil (L) & - & 35.0 & 23.0 & 41.0 & 59.0 & 41.6 & 22.9 & 18.7 & 40.6 & 32.1 & 12.0 & 0.23 & 0.44 & 0.17 & 1.48 & 11.12 \\
\hline
\end{tabular}

* composition of lateritic clay is for [8].

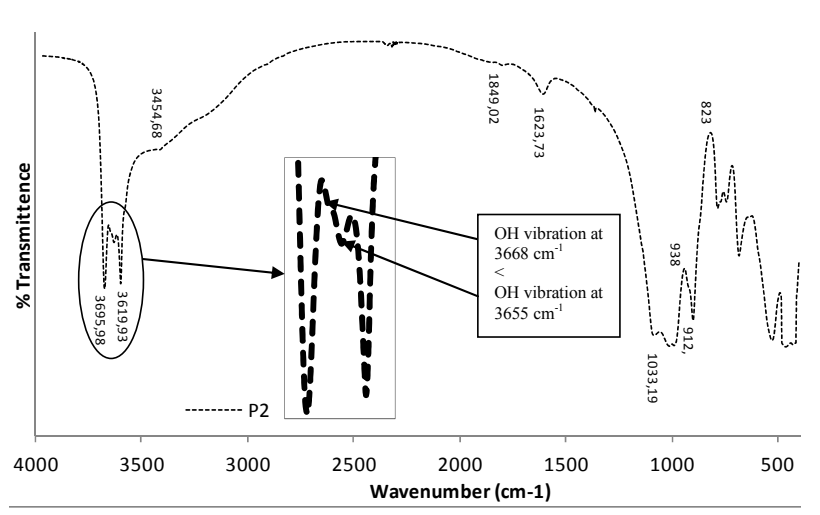

Figure 4. IR curves of alluvial clay from pit P2.

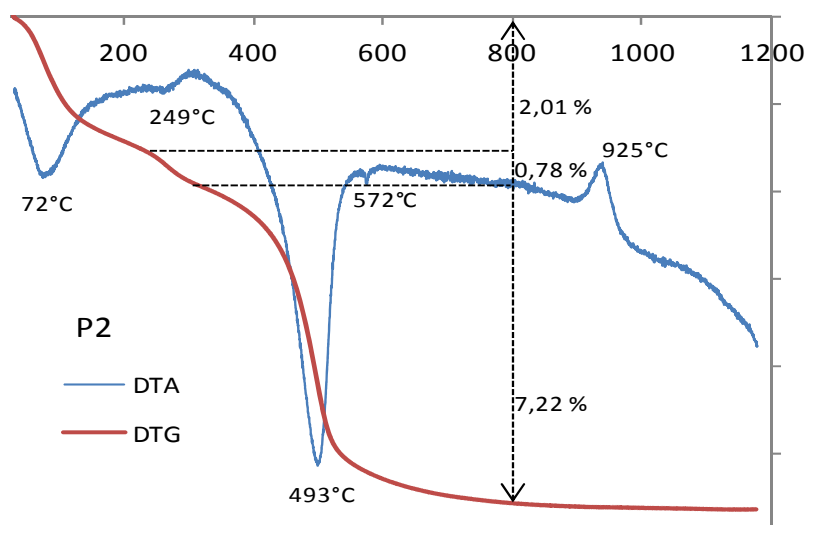

Figure 5. Thermal curves of alluvial clay from pit P2.

$70 \%$ of clay fraction, $15 \%$ of silt and $10 \%$ of sand. The greatest amount of fines particles (90\%) suggests that this soil belongs to the very heavy clay group according to the Belgian texture of soil [34]. For the lateritic clay (L), [8] reported $35 \%$ of clay fraction, $25 \%$ of silt, $40 \%$ of sand and trace of gravel $(1 \%-2 \%)$. In the Casagrand diagram (Figure 6), the alluvial clay belongs to the field of plastic clay while the lateritic clayey soil belongs to the medium plastic group. The great proportion $(70 \%)$ of the clays fractions $(<2 \mu \mathrm{m})$ in the alluvial clay associated with their high plasticity (46\%) favor a high shrinkage, which make them unsuitable (at the pure state) for bricks manufacture [2]. In the ceramic industry, the plastic clays are generally used to amend non fusible clays $[2,8,35]$. Since lateritic clay soil do not integrate any fluxing min-

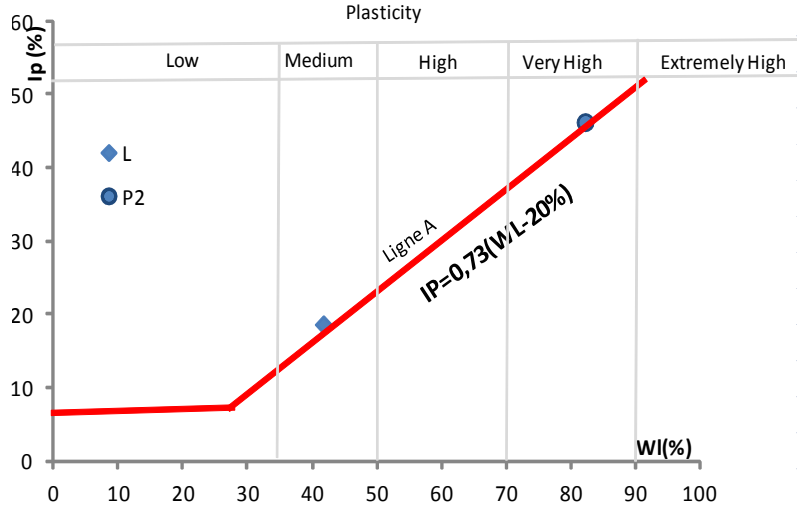

Figure 6. Position of alluvial clay "P2" and lateritic clay soil " $L$ " in the Casagrand diagram.

erals, the presence of feldspar, illite and smectite in the alluvial clay could assure a good fusibility of the bricks resulting from the mixture of the alluvial clay and laterite.

\subsection{Technological Properties of Bricks}

The linear shrinkage, water absorption and the flexural strength were used to access the fusibility of the mixture formulations. The values of linear shrinkage of the bricks increase with increasing the firing temperature (Figure 7). At $900^{\circ} \mathrm{C}$, the values are less than $2 \%$, rising to $3 \%$ $4 \%$ at $1000{ }^{\circ} \mathrm{C}$ and $\sim 8 \%$ for brick resulting from the composition of $100 \%$ alluvial clay (L0\%). Beyond $1000^{\circ} \mathrm{C}$, the shrinkage is very high $(>8 \%)$ for all the mixtures. This shrinking behavior, primarily attributed to the degree of sintering, is probably due to rearrangement reactions within the firing product associated to partial sintering of some phases [36]. The $100 \%$ alluvial clay formulation (L0\%) has a higher linear shrinkage comparatively to the pure clay admixed with laterite, suggesting a positive effect of laterite addition in the shrinkage.

The water absorption values decrease with increasing temperature (Figure 8). These values are in the range $20 \%-25 \%$ at $900^{\circ} \mathrm{C}-1000^{\circ} \mathrm{C}$ and below $20 \%$ above $1000^{\circ} \mathrm{C}$. The addition of laterite slightly increases the percentage of water absorption, probably due to the relatively refractory character of the laterite, which mitigates the formation of vitreous phases at higher temperatures. 


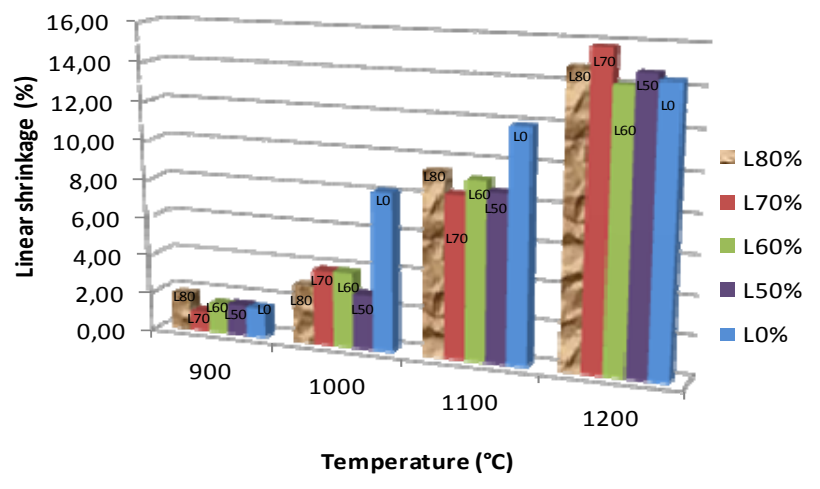

Figure 7. Evolution of linear shrinkage.

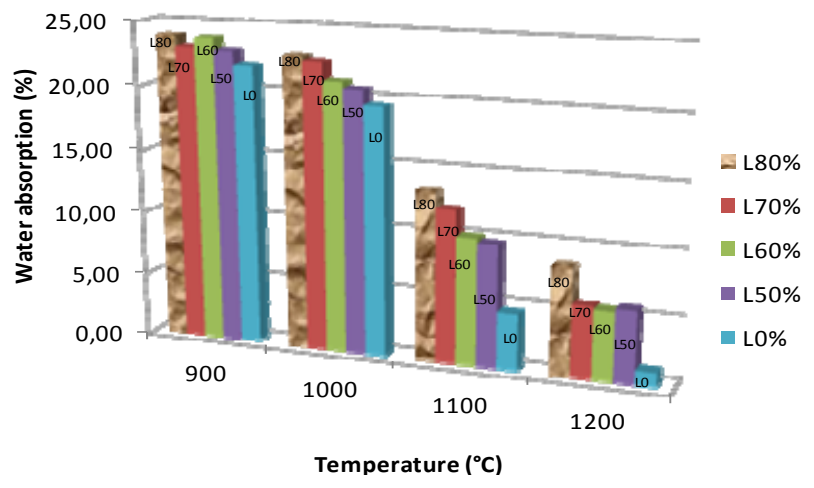

Figure 8. Evolution of water absorption.

Considering the reported value (less than $20 \%$ ) of water absorption recommended for fired brick in tropical countries [37], the bricks made at temperature $>1000^{\circ} \mathrm{C}$ remain acceptable according to the British Standard [38]. All the studied bricks present an increase of the bending strength from $900^{\circ} \mathrm{C}$ to $1100^{\circ} \mathrm{C}$ and a decrease above $1100^{\circ} \mathrm{C}$ (Figure 9). The low values of bending strength at $1200^{\circ} \mathrm{C}$ are probably due to the appearance of cracks at this temperature. At temperatures up to $1000^{\circ} \mathrm{C}$, the bending strength is between $2 \mathrm{MPa}$ and $7 \mathrm{MPa}$, rising to 6 $\mathrm{MPa}-12 \mathrm{MPa}$ for temperatures above $1000^{\circ} \mathrm{C}$. The admixture of laterite in the alluvial clay slightly decreases the values of bending strength at $900^{\circ} \mathrm{C}-1100^{\circ} \mathrm{C}$, this may arise from the ongoing reaction of the Fe-bearing phases at this temperature [39]. According to Sigg (1991) [40], $7 \mathrm{MPa}$ is the minimum value required for normal fired brick and $1050^{\circ} \mathrm{C}$ was reported as the maximum temperature for the production of fired bricks. The alluvial clay studied, admixed with the laterite, could be used for industrial production of fired bricks and the minimal firing temperature require is $1050^{\circ} \mathrm{C}$.

\section{Conclusion}

The detailed mapping of Ebebda's clay site has been carried out, followed by some characterization. Ebebda's area offers a great potentiality for the exploitation of raw

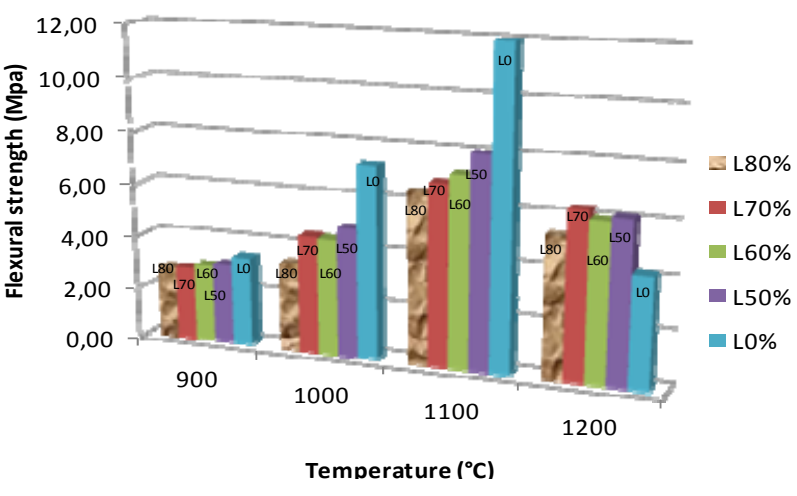

Figure 9. Evolution of flexural strength.

clay materials for the ceramic industry, particularly on the left bank of the Sanaga River. The clayey layer (average thickness $\sim 2.2 \mathrm{~m}$ ) is overlain by a thin layer of top soil. The clay material is estimated at $2.2 \times 10^{5}$ tonnes over the studied area (05 hectares). The mineralogical paragenesis is made by quartz $(40 \%)$, kaolinite $(30 \%)$ and illite (7\%). K-feldspar, goethite, hematite and smectite are also present. From the physico-chemical properties, the alluvial clays were classified as plastic clays. Our experiments demonstrate that the admixture of lateritic clay has a positive effect in reducing the shrinkage. However, the presence of lateritic clays slightly increases the water absorption of the bricks and decreases the bending strength. The best properties were obtained for a mixture of $70 \%$ of laterite with $30 \%$ of alluvial clays.

\section{Acknowledgements}

This study was carried out within the program Local Material, Society and Development-MSD of the Local Material Promotion Authority-MIPROMALO, Yaoundé Cameroun. The authors are grateful to Pr. Uphie Chinje Melo, the Managing Director of this institution. A one year grant from the University of Liege (Belgium) to Aubin Nzeukou has permitted to complete the laboratory analyses.

\section{REFERENCES}

[1] H. H. Murray, "Applied Clay Mineralogy Today and Tomorrow," Clay Minerals, Vol. 34, No. 1, 1999, pp. 39-49. doi:10.1180/000985599546055

[2] G. M. Reeves, I. Sims and J. C. Cripps, "Clay Materials Used in Construction," Geological London Society, London, 2006.

[3] H. Baccour, M. Medhioub, T. Jamoussi and A. Daoud, "Mineralogical Evaluation and Industrial Applications of the Triassic Clays Deposits, Southern Tunisia," Journal of Material Characterization, Vol. 59, No. 11, 2008, pp. 1613-1622. doi:10.1016/j.matchar.2008.02.008

[4] C. Nkoumbou, A. Njoya, D. Njopwouo and R. Wandji, "Intérêt Economique des Matériaux Argileux," Acte de la 
Première Conférence sur la Valorisation des Matériaux Argileux au Cameroun, 11 au 12 avril 2001, pp. 1 à 12.

[5] P. M. Thibault and P. Le Berre, "Recherche D'Argile pour Briques dans la Région de Yaoundé, Douala et Edéa," Rapport BRGM. CRMO 65; MIMEE, Yaoundé, Cameroun, 1985.

[6] P. G. Ntep, J. Dupry, E. Kalngui, O. Matip and A. Fombutu, "Ressources Minérales du Cameroun," Notice Explicative de la Carte Thématique, MINEE, 2001.

[7] R. Yongue-Fouateu, “Contribution à L'étude Pétrologique de L'Altération et des Faciès de Cuirassement Ferrugineux des Gneiss Migmatitiques de la Région de Yaoundé," Thèse 3ème cycle Univ. Yaoundé, 1986.

[8] G. F. Ngon Ngon, F. R. Yongue, L. D. Bitom and P. Billong, "A Geological Study of Clayey Laterite and Clayey Hydromorphic Material of the Region of Yaoundé (Cameroon): A Prerequisite for Local Material Promotion," Journal of African Earth Sciences, Vol. 55, No. 1-2, 2007, pp. 69-78. doi:10.1016/i.jafrearsci.2008.12.008

[9] J. M. Regnoult, "Synthèse Géologique du Cameroun," Ministère des Mines, de l'Eau et de l'Energie, République du Cameroun, 1986.

[10] A. B. Tchamba, A. N. Nzeukou, R. F. Tené and U. C. Melo, "Building Potentials of Stabilized Earth Blocks in Yaounde and Douala (Cameroon)," International Journal of Civil Engineering Research, Vol. 3, No. 1, 2012, pp. $1-14$.

[11] L. Mbumbia, A. Mertens de Wilmars and J. Tirlocq, "Performance Characteristics of Lateritic Soil Bricks Fired at Low Temperatures: A Case Study of Cameroon," Construction and Building Materials, Vol. 14, No. 3, 2000, pp. 121-131. doi:10.1016/S0950-0618(00)00024-6

[12] J. P. Nzenti, P. Barbey, J. Macaudière and D. Soba, "Origin and Evolution of Late Precambrian High-Grade Yaounde Gneisses (Cameroon)," Precambrian Research, Vol. 38, No. 2, 1988, pp. 91-109. doi:10.1016/0301-9268(88)90086-1

[13] S. F. Toteu, W. R. Van schmus, J., Penaye and J. B. Nyobe, "U-Pb and Sm-Nd Evidence for Eburian and Panafrican High Grade Metamorphism in Cratonic Rocks of Southern Cameroon," Precambrian Research, Vol. 67, No. 3-4, 1994, pp. 321-347. doi:10.1016/0301-9268(94)90014-0

[14] J. E. Prentice, "Evaluation of Brick Clay Reserves," Transaction of the Institution of Mining and Metallurgy, Section B, Applied Earth Sciences, Vol. 97, No. 1, 1988, pp. 9-14.

[15] J. Konta and R. A. Künher, "Integrated Exploration of Clay Deposits: Some Changes of Strategy," Applied Clay Sciences, Vol. 11, No. 5-6, 1997, pp. 273-283. doi:10.1016/S0169-1317(96)00027-0

[16] A. Cailleux, "Notice sur le Code des Couleurs des sols," Boubée, 1992.

[17] D. M. Moore and C. Reynolds Robert Jr., "X-Ray Diffraction and the Identification and Analysis of Clay Minerals," Oxford University Press, Oxford, 1989.

[18] H. E Cook, P. D Johnson, J. C. Matti and I. Zemmels, "Methods of Sample Preparation and X-Ray Diffraction. Data
Analysis, X-Ray Mineralogy Laboratory, Deep Sea Drilling Project," University of California, Riverside, Contribution n 74-5, 1975, pp. 999-1007.

[19] T. Boski, J. Pessoa, P. Pedro, J. Thorez, J. M. A. Dias and I. R. Hall, "Factors Governing Abundance of Hydrolysable Amino Acids in the Sediments from the N.W. European," Continental Margin $\left(47-50^{\circ} \mathrm{N}\right)$. Progress Oceanography, Vol. 42, No. 1-4, 1998, pp. 145-164. doi:10.1016/S0079-6611(98)00032-9

[20] A. Oliveira, F. Rocha, A. Rodrigues, J. Jouanneau, A. Dias, O. Weber and C. Gomes, "Clays Minerals from the Sedimentary Cover from Northwest Iberian Shelf," Progress in Oceanography, Vol. 52, No. 2-4, 2002, pp. 233247. doi:10.1016/S0079-6611(02)00008-3

[21] J. Vidinhia, F. Rocha, C. Andrade, C. Gomes and C. Freitas, "Clays Minerals-A Mineralogical Tool to Distinguish Beach from Dune Sediments," Journal of Coastal Research, SI50 (Proceedings of the 9th International Coastal Symposium), 2007, pp. 216-220.

[22] ASTM-America Society for Testing Materials, "Standard Test Method for Particle-Size Analysis of Soils," 1998, ASTM D-422-63.

[23] ASTM-America Society for Testing Materials, "Standard Test Method for Liquid Limit, Plastic Limit, and Plasticity Index of Soils," 2000, ASTM D-4318.

[24] ASTM-American Society for Testing and Materials, "Water Absorption, Bulk Density, Apparent Porosity, and Apparent Specific Gravity of Fired Whiteware Products," 1972, C 373-72.

[25] ASTM-American Society for Testing and Materials, "Flexural Properties of Ceramic Whiteware Materials," 1977 , C 674-77.

[26] C. I. Fialips, S. Petit and A. Decarreau, "Hydrothermal Formation of Kaolinite from Various Metakaolins," Clays Minerals, Vol. 35, No. 3, 1999, pp. 559-572. doi: $10.1180 / 000985500547025$

[27] O. Lietard, "Contribution a L'étude des Propriétés Physicochimiques, Cristallographiques et Morphologiques Des kaolins," Thèse d'Etat, Ins. Polytech. Lorraine, Nancy, 1977.

[28] J. M. Cases, O. Lietard, J. Yvon and J. F. Delon, "Etude des Propriétés Cristallochimiques, Morphologiques, Superficielles de Kaolinites Désordonnées," Bullettin Minéralogique, Vol. 105, No. 5, 1982, pp. 439-456.

[29] J. M. Amigo, J. Bastida, A. Sanz, M. Signes and J. Serrano, "Crystallinity of Lower Cretaceous Kaolinites of Teruel (Spain)," Applied Clay Sciences, Vol. 9, No. 1, 1994, pp. 51-69. doi:10.1016/0169-1317(94)90014-0

[30] Th. Delineau, Th. Allard, J. P. Muller, O. Barres, J. Yvon and J. M. Cases, "FTIR Reflectance vs EPR Studies of Structural Iron in Kaolinites," Clay and Clay Minerals, Vol. 42, No. 3, 1994, pp. 308-320. doi:10.1346/CCMN.1994.0420309

[31] G. E. Christidis, "Industrial Clays. European Mineralogical Union, Notes in Mineralogy," Vol. 9, Chapter 9, 2011, pp. 341-414.

[32] H. Celik, "Technological Characterization and Industrial Application of Two Turkish Clays for the Ceramic Indus- 
try," Applied Clay Science, Vol 50, No. 2, 2010, pp 245254. doi:10.1016/j.clay.2010.08.005

[33] M. Sakizci, B. A. Erdogan and E. Yörükogullari, "Thermal Behavior and Immersion Heats of Selected Clays from Turkey," Journal of Thermal Analysis Calorimetry, Vol. 98, No. 2, 2009, pp. 429-436. doi:10.1007/s10973-009-0294-y

[34] A. Richer de Forges, C. Feller, M. Jamagne and D. Arrouays, "Etudes et Gestion des Sols," Vol. 15, No. 2, 2008, pp. 97-111.

[35] D. A. C. Manning, "Introduction to Industrial Mineral," Chapman \& Hall Edition, London, 1995. doi:10.1007/978-94-011-1242-0

[36] J. Lemaitre, J. Leonard and B. Delmon, "The Sequence of Phases in the $900^{\circ} \mathrm{C}-1050^{\circ} \mathrm{C}$ Transformation of Metakaolinite," Proceeding of International Clay Conference,
Vol. 60, No. 1-2, 1977, pp. 37-43.

[37] C. U. Melo, E. Kamseu and C. Djangang, "Effect of Fluxes on the Fired Properties between $950^{\circ} \mathrm{C}-1050^{\circ} \mathrm{C}$ of Some Cameroonian Clays," Tiles \& Bricks International, Vol. 19, No. 6, 2003, pp. 57-69.

[38] British Standard Institution, "British Standard Specifications for Clays Bricks," London, BS 3921, 1985.

[39] J. Y. Y. Andji, A. Abba Toure, G. Kra, J. C. Jumas, J. Yvon and P. Blanchart, "Iron Role on Mechanical Properties of Ceramics with Clays from Ivory Coast," Ceramics International, Vol. 35, No. 2, 2009, pp. 571-577. doi:10.1016/i.ceramint.2008.01.007

[40] J. Sigg, "Les Produits de Terre Cuites," Septima, Paris, 1991. 